\title{
Kleptoparasitism and territoriality in the Snail Kite Rostrhamus sociabilis (Accipitriformes: Accipitridae) in the Complejo Güija, El Salvador
}

\author{
Abizai Clemente Chinchilla-Rodríguez ${ }^{1,2} \&$ Iliana Guadalupe Barias-Álvarez ${ }^{1}$ \\ Escuela de Biología, Universidad de El Salvador, San Salvador, El Salvador. \\ Corresponding author: chinchillaabizai@gmail.com
}

Received on 24 July 2018. Accepted on 04 December 2018.

\begin{abstract}
We present the observations of some kleptoparasitic and territorial interactions in the Snail Kite (Rostrhamus sociabilis), following focal individuals from January to May 2017 in two wetlands of El Salvador. Those interactions were performed during their food searching and managing of prey on perch. We observed two attempts of kleptoparasitism from Great-tailed Grackle (Quiscalus mexicanus) to R. sociabilis. On the first case, a flock of Q. mexicanus chased an adult Snail Kite, which had captured a snail; on the second case, a male of $Q$. mexicanus tried to steal a young Snail Kite's prey, which was managing its prey on perch. On both cases in response to the attack, two individuals chose to change perch to complete the consumption of its prey. We also observed an intent of kleptoparasitism between two male Snail Kites, after the attack, on perch the chased bird released the snail and moved to another site, meanwhile, the attacker ended up eating the snail. We attribute this observation to a kleptoparasitic behavior, related to water stress and variations in prey availability. We recorded Snail Kite's territorial behavior between the species and against other raptors, as a way to protect their feeding territories. With these observations, we provide some information about the ecological behavior of the species in El Salvador. We stress the need to carry out research related to the interaction between R. sociabilis and $Q$. mexicanus on its feeding sites, focusing in the effect of water scarcity and snail availability on the behavior of the Snail Kite.
\end{abstract}

KEY-WORDS: ethology, Great-tailed Grakle, raptors, specialist, wetlands.

\section{INTRODUCTION}

In a community structure, the interaction of species can be either positive or negative (Jaksic \& Marone 2001). The result of the interactions generates a dynamic equilibrium that determines the structure of the community and the richness. Among interactions that contribute to this dynamic flow are: competition, predation (including parasitism) and mutualism (Dhondt 2012). Competition is an interaction between individuals of the same (intraspecific) or distinct (interspecific) species, it is caused by the common need of a limited resource in the habitat that species share, which leads to the reduction of survival, growth and/or reproduction of the competing individuals (Begon et al. 1995).

Food theft or kleptoparasitism, can occur in many groups of animals, however, is more common among birds, where parents which provide food to their offspring may be more vulnerable to be attacked by organism of the same species (intraspecific attacks) or other species (interspecific attacks) (Brockmann \& Barnard 1979, Gaglio et al. 2018). This could lead to a decrease in the feeding rates, due to the time spent in avoiding kleptoparasitic attacks (Gaglio et al. 2018).

The Snail Kite (Rostrhamus sociabilis) has a wide geographical distribution from Florida (USA) to Uruguay and Argentina (Sick 1997), it is probably one of the most morphologically specialized species among raptors, since its hook-shaped, thin and curved beak allows it to easily cut the connecting muscle and to extract the meat completely from the shell, which is the main prey that makes up its diet (Méndez et al. 2006, Rueda \& Wiebe 2014, Chapman $\&$ Bolen 2015). In this study we present observations of kleptoparasitism and territoriality in $R$. sociabilis populations in two wetlands of the Complejo Güija, with the aim of describing those behaviors and contributing to the knowledge of the ethology of this species in the country.

\section{METHODS}

Complejo Güija is located in western El Salvador, in the Santa Ana department, municipality of Metapán $\left(14^{\circ} 17^{\prime} \mathrm{N} ; 8^{\circ} 29^{\prime} \mathrm{W}\right)$. It is a RAMSAR site (MARN 2016) and its extension includes 47.200 ha. The main 
lake has an area of $42 \mathrm{~km}^{2}$ of which $76.7 \%$ corresponds to El Salvador and the rest to Guatemala. This complex includes the Metapán Lagoon, the Güija Lake and portions of the Natural Protected Area San Diego y La Barra (Herrera \& Rivera 2001, Herrera 2005). We made the observations in the northern sector of the Güija Lake $\left(14^{\circ} 17.584^{\prime} \mathrm{N}\right.$; 89 $\left.31.983^{\prime} \mathrm{W}\right)$ (Site 1$)$, and in the sector of Rincón del Cuje, in the Metapán Lagoon $\left(14^{\circ} 18.548^{\prime} \mathrm{N}\right.$; $89^{\circ} 29.288^{\prime} \mathrm{W}$ ) (Site 2).

We performed 11 visits to each site in the period of January to May 2017, from 7:00 h to 12:30 h. The information of the bird's behavior was obtained using the focal individual method (Lehner 1998), which is, briefly, a selection of an individual that started to forage being the focus of the observation for $10 \mathrm{~min}$, at a distance no less than $15 \mathrm{~m}$, to prevent the species from modifying its behavior due to disturbance. In each observation, we recorded intra and interspecific interactions, with emphasis on territoriality. At the end of the observation of one focal individual, we waited for $10 \mathrm{~min}$ to select a new one, making sure that the specimen was not the same that we were observing previously.

\section{RESULTS \& DISCUSSION}

\section{Great-tailed Grakle vs. Snail Kite}

We observed agonistic interactions from Quiscalus mexicanus, which in Site 1 performed flock chases on an adult $R$. sociabilis which had captured a snail. These persecutions were carried out as an attempt to steal the snail captured by the species. Due to these persecutions the Snail Kite moved to another place with its prey, without presenting aggressive behavior against its persecutors. Similar behavior of kleptoparasitism was observed on a juvenile, which was managing its prey on the perch and was frequently interrupted by a male Q. mexicanus (Fig. $1 \mathrm{~A})$, which made attempts to steal the snail and made a constant vocalization. In response to the attack, the juvenile chose to change the perch to end the consumption of its prey. On Site 2 we observed the displacement by an individual of $Q$. mexicanus against a female $R$. sociabilis (Fig. 1B). This behavior of kleptoparasitism against $R$. sociabilis has been observed by Sykes-Jr. (1987) in $Q$. major, a species that made constant attacks against Snail
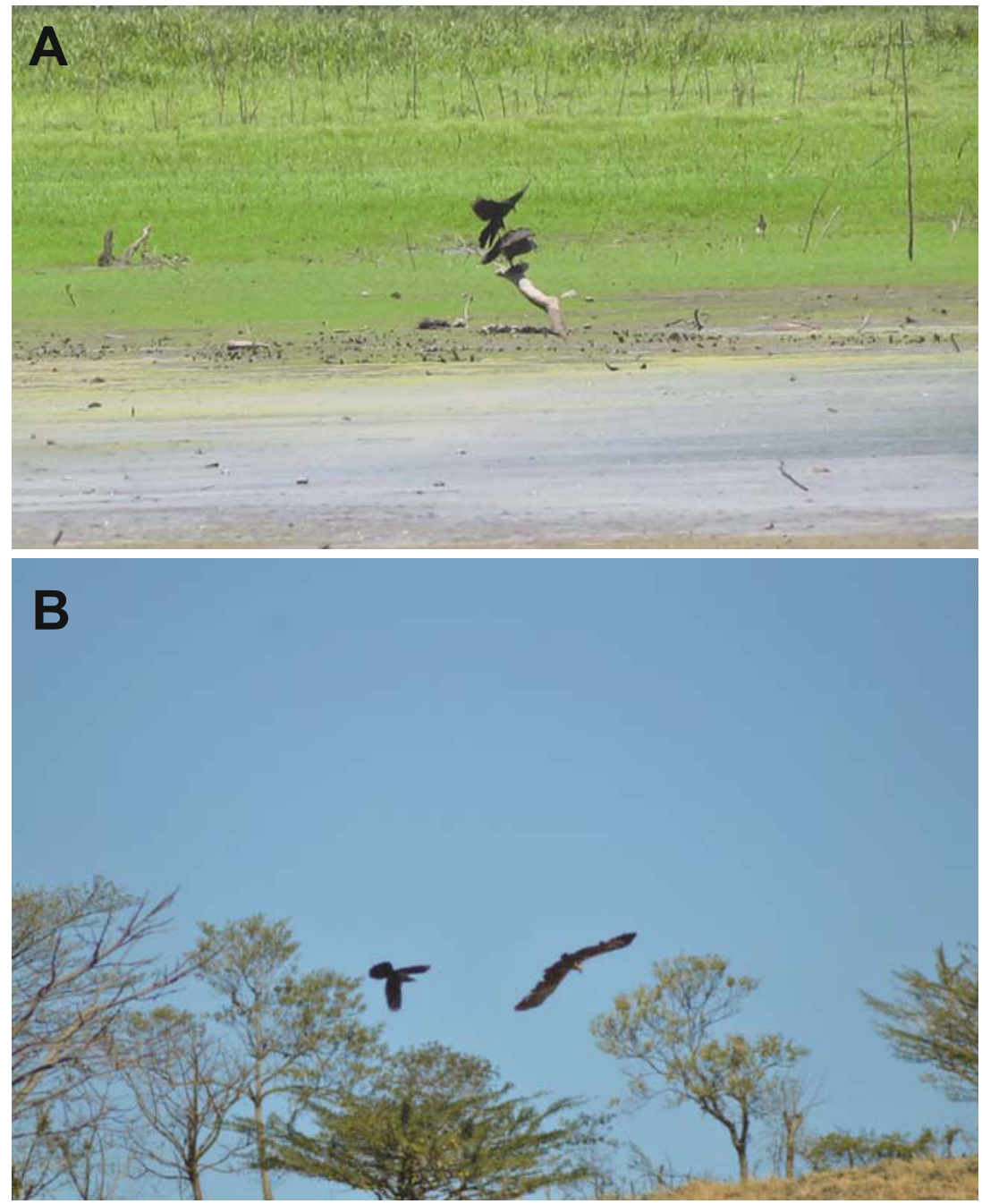

Figure 1. Attacks and intent of kleptoparasitism of a male Quiscalus mexicanus towards a juvenile Rosthramus sociabilis (A). Displacement of a female $R$. sociabilis by a male $Q$. mexicanus $(\mathbf{B})$. 
Kites, while it was on a perch or in flight. With our observations we documented for the first time in the zone this behavior between $R$. sociabilis and Q. mexicanus. We even observed an individual of $Q$. mexicanus carrying a snail in its beak. Therefore, we suggest that future studies focused on the feeding interaction of these species.

\section{Snail Kite vs. Snail Kite}

In Site 1 we observed an intraspecific attack of $R$. sociabilis against another individual of the same species, which had a prey on a feeding perch. Due to the attack, the Snail Kite released the snail and moved to another site. The Snail Kite which finished the attack ended up eating the snail. We attribute this observation to a kleptoparasitic behavior. Miller \& Tilson (1985) observed kleptoparasitism between $R$. sociabilis against Limpkin Aramus guarauna, when the availability of snails was low, due to the decrease in water level or the increase in vegetation height. We observed similar conditions (in relation to the availability of snails) to those observed by Miller \& Tilson (1985) on the day of the kleptoparasitic interaction, because snail hunted per h was low: 0.52 snails/h. This kleptoparasitic behavior may be more frequent according to wetland conditions, such as low water levels and low prey availability. For this reason, it is important to evaluate the behavior of the Snail Kite during these periods of stress.

\section{Territoriality}

On Site 1, we recorded interactions of $R$. sociabilis with other raptors: on one occasion, two juvenile Geranoaetus albicaudatus were displaced by persecution and vocalization by a male $R$. sociabilis who was hunting. Similar observations were made by Haverschmidt (1970) in Suriname, who documented the persecution of R. sociabilisagainst Buteogallus meridionalis, which had captured a small mammal. In our observations, the attack was probably carried out because $R$. sociabilis was in foraging activities and both individuals of $G$. albicaudatus slightly interrupted their activity, since the diet of this species is composed mainly by rodents, amphibians, reptiles, carrion and even small birds (Dunne et al. 2012), making improbable territorial behavior.
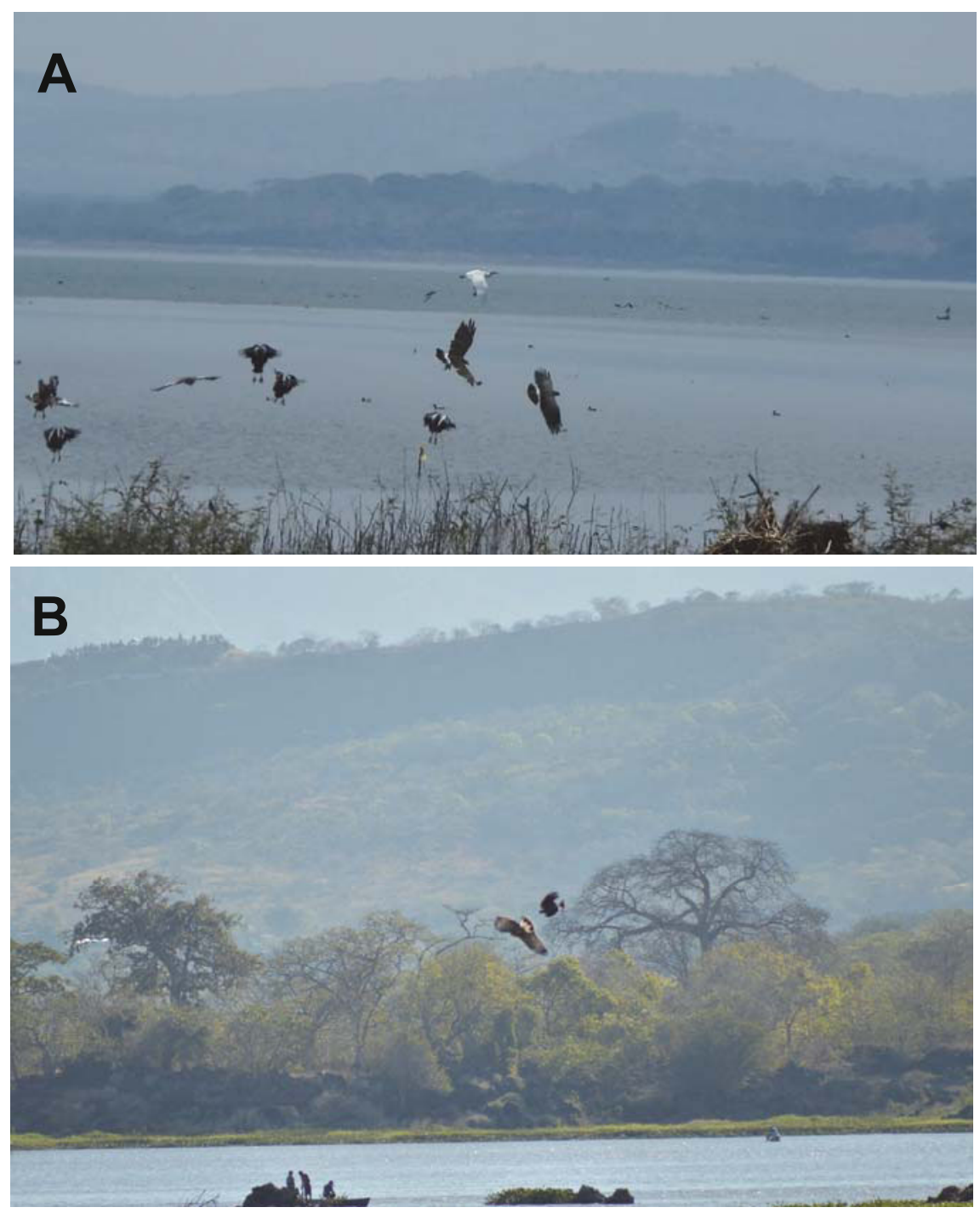

Figure 2. Territorial behavior for the food resource among Rosthramus sociabilis in both studied sites $(\mathbf{A}=$ site $1 ; \mathbf{B}=$ site 2$)$. 
On Site 2, we observed a territorial fight between a female $R$. sociabilis and Caracara cheriway: the female vocalized while in flight to get $C$. cheriway away from the sector, in the same way it made attacks with its claws without making contact. We also recorded interactions against Buteogallus anthracinus; in this case, it was this species which removed $R$. sociabilis from the site with vocalizations and without presenting aggressiveness with its claws. This area has been described as a feeding and hunting site for B. antrhacinus (Molina 2013). In the same way we observed an active nest to the east of the foraging site of $R$. sociabilis, so the attacks could be related to territoriality.

We registered territorial behaviors among Snail Kite's in both sites. In Site 1 , an adult male was attacked while moving with its prey (Fig. 2A), causing consumption of its prey approximately $20 \mathrm{~m}$ away from the site where the attack occurred. In the interaction site, the capture of snails by Snail Kites was frequent. Snyder \& Snyder (1970) mention that $R$. sociabilis forages in common feeding areas and sometimes some individuals usually exhibit territorial behaviors in defense of small areas $\left(2.25 \mathrm{~km}^{2}\right)$ where they constantly capture snails, preventing other individuals from hunting. The defense of its territory is carried out when the availability of snails is high, while in conditions of low abundance. The defense of territory is not carried out, because this implies energy expended (Snyder \& Snyder 1970). Unlike these observations, the day of the interaction the snail intake was low, with 1.33 snails consumed per h. In Site 2 we recorded the displacement of individuals in search of food or feeding on the perch. This behavior is attributed in this case to the defense of food territories due to a high abundance of snails, similar to the observations of Snyder \& Snyder (1970). On the day of observation, we recorded the maximum amount of snails consumed/h (7.33). Bourne (1985) and Posso et al. (2012) also describe this territorial behavior exhibited by males, with vocalizations and persecutions against intruders in their food territories. We conclude that the territorial behavior of the Snail Kite in both wetlands is frequent and this can increase in periods of low snail availability.

\section{ACKNOWLEDGEMENTS}

To Idalma Aldana and the rangers of the sites for supporting the development of this investigation. We are in debt to José Pablo for the English translation of the original manuscript and to David Rodríguez for kindly checking the English grammar.

\section{REFERENCES}

Begon M., Harper J.L. \& Townsend C.R. 1995. Ecología: individuos, poblaciones y comunidades. Barcelona: Ediciones Omega.

Bourne G.R. 1985. Field test of micropatch and prey-size selection by Snail Kites Rostrhamus sociabilis. Ibis 127: 141-147.

Brockmann H.J. \& Barnard C.J. 1979. Kleptoparasitism in birds. Animal Behavior 27: 487-514.

Chapman B.R. \& Bolen E.G. 2015. Ecology of North America. Oxford: John Wiley \& Sons Ltd.

Dhondt A.A. 2012. Interspecific competition in bird. New York: Oxford University Press.

Dunne P., Sibley D. \& Sutton C. 2012. Hawks in fight. Boston: Houghton Mifflin Harcourt.

Gaglio D., Sherley R.B., Cook T.R., Ryan P.G. \& Flower T. 2018. The cost of kleptoparasitism: a study of mixed-species seabird breeding colonies. Behavioral Ecology 29: 939-947.

Haverschmidt F. 1970. Notes on the Snail Kite in Surinam. Auk 87: 580-584.

Herrera N. \& Rivera R. 2001. Complejo de Güija, Metapán, El Salvador, Centro América: Propuesta de Sitio Ramsar. San Salvador: Ministerio de Medio Ambiente y Recursos Naturales.

Herrera N. 2005. Evaluación ambiental del complejo Lago de Güija. San Salvador: Ministerio de Medio Ambiente y Recursos Naturales.

Jaksic F. \& Marone L. 2001. Ecología de comunidades. Santiago: Universidad Católica de Chile.

Lehner P.N. 1998. Handbook of ethological methods. Cambridge: Cambridge University Press.

MARN [Ministerio de Medio Ambiente y Recursos Naturales]. 2016. Plan de manejo Parque Nacional San Diego y San Felipe Las Barras. El Salvador: MARN.

Méndez P., Curti M., de Montuto K. \& Benedetti A. 2006. Las aves rapaces - guía didáctica de educación ambiental. Panamá: Fondo Peregrino.

Miller B.W. \& Tilson R.L. 1985. Snail Kite kleptoparasitism of Limpkins. Auk 102: 170-171.

Molina D. 2013. Distribución de las aves rapaces diurnas residentes en el Parque Nacional San Diego-La Barra, municipio de Metapán, departamento de Santa Ana. Thesis Licenciatura in Biology. Universidad de El Salvador.

Posso S.R., Cintra F.B. \& Frias J. 2012. Temporal influence on foraging strategies, territoriality and nomadic tendencies of Snail Kite, Rosthramus sociabilis (Viellot, 1817) in an urban Neotropical wetland. Brazilian Journal of Biology 72: 235-241.

Rueda C. \& Wiebe A. 2014. Snail Kite (Rostrhamus sociabilis). In: Schulenberg T.S. (ed.) Neotropical birds online. Ithaca: Cornell Lab of Ornithology. https://neotropical.birds.cornell.edu/SpeciesAccount/nb/species/snakit (access on 21 September 2018).

Sick H. 1997. Ornitologia brasileira. Rio de Janeiro: Nova Fronteira.

Snyder N. \& Snyder H.A. 1970. Feeding territories in the Everglades Kite. Condor 72: 492-493.

Sykes-Jr. P.W. 1987. The feeding habits of the Snail Kite in Florida, USA. Colonial Waterbirds 10: 84-92.

Associate Editor: Cristiano S. Azevedo. 